\title{
Peran Kepala Sekolah Sebagai Educator dalam Meningkatkan Kompetensi Teknologi Informasi dan Komunikasi
}

\author{
Melysa Ristianti' ${ }^{1}$, Saipul Annur' ${ }^{2}$ Maryamah $^{3}$ \\ ${ }^{1}$ SMP Negeri 29 Palembang, Sumatera Selatan, Indonesia \\ 2,3Universitas Islam Negeri Raden Fatah Palembang, Sumatera Selatan, Indonesia \\ lisamelysa2@gmail.com
}

\begin{abstract}
This research is a research on the role of school principals in improving the competence of Information and Communication Technology teachers which will discuss how the role of principals in improving teacher ICT competencies, how the competence of teachers' ICT and supporting and inhibiting factors in increasing Information Technology competence Teacher communication at SMP Negeri 10 Palembang. The method used in this study uses a qualitative type, and a phenomenological approach. Data research techniques use observation, interviews and documentation through data analysis. In validating the data found in the research field the results use source triangulation and technical triangulation. The research results: first The role of the head schools as educators in improving teacher ICT competence are implementing strategies such as holding training, creating a conducive work climate such as providing ICT facilities, always reminding teachers of the importance of ICT in the present and providing motivation in the form of praise and reprimands. Second, the ICT competence of teachers includes computers, the use of software based on the child's condition, the ability of the teacher, software that is practical, simple, efficient, and multifunctional and applies techniques online and offline. Third, supporting factors include teachers' awareness of learning, adequate equipment, and teacher educational background. Barring factors include the limited capacity caused and the budget for ICT training that has not been included in the school budget at the beginning of the year
\end{abstract}

Keywords: Principal, Educator, ICT, Teacher.

\begin{abstract}
Abstrak. Penelitian ini merupakan penelitian tentang peran kepala sekolah dalam meningkatkan kompetensi TIK guru yang akan membahas tentang bagaimana peran kepala sekolah dalam meningkatkan kompetensi TIK guru, bagaimana kompetensi TIK guru serta faktor pendukung dan penghambatdalam meningkatkan kompetensi TIK di SMP Negeri 10 Palembang. Metode penelitian yang digunakan dalam penelitian ini menggunakan jenis kualitatif, dan pendekatan fenomenologi.Teknik pengumpulan data menggunakan observasi, wawancara dan dokumentasi dengan melalui analisis data. Dalam memvalidasi data yang ditemukan dilapangan peneliti menggunakan trianggulasi sumber dan trianggulasi teknik. Adapun hasil penelitin yaitu: pertama Peran kepala sekolah sebagai educator dalam meningkatkan kompetensi TIK guru adalah menerapkan strategi seperti mengadakan pelatihan, menciptkan iklim kerja yang kondusif seperti menyediakan fasilitas TIK, selalu mengingatkan guru akan pentingnya TIK pada masa sekarang serta memberikan motivasi berupa pujian dan teguran. Kedua, Kompetensi TIK guru meliputi pengoperasian komputer,penggunaan software pengajaran berdasarkan kondisi anak, kemampuan guru, software yang praktis, simple, efisien, dan multifungsi dan menerapkan Teknik pengajaran secara online dan offline. Ketiga, faktor pendukung meliputi kesadaran guru-guru untuk belajar,peralatan yang memadai, latar belakang pendidikan guru. Faktor penghambat meliputi keterbatasan kemampuan disebabkan usia dan anggaran pelatihan TIK yang belum dimasukkan dalam anggaran sekolah di awal tahun.
\end{abstract}

Kata Kunci: Kepala Sekolah, Educator, TIK, Guru. 


\section{PENDAHULUAN}

Perkembangan kemajuan Teknologi Informasi dan Komunikasi (TIK) membawa pengaruh yang signifikan terhadap pergeseran paradigma pembelajaran disekolah. Menurut Sukirman yang dikutip oleh Rivalalana dalam jurnalnya mengemukakan bahwa, paradigma pembelajaran yang sebelumnya berfokus kepada guru (teacher-centered learning) bergeser menjadi pembelajaran yang berfokus kepada peserta didik (student-centered learning). Guru tidak lagi berperan sebagai satu-satunya sumber belajar bagi peserta didik. Guru hanya menjadi salah satu dari berbagai sumber belajar. Artinya, peserta didik, selain belajar dari guru, sangat dimungkinkan juga untuk dapat belajar dari berbagai sumber belajar lain di luar guru (Rahmi Rivalian, 2014).

Teknologi informasi dan komunikasi (TIK) membawa banyak manfaat dalam bidang pendidikan antara lain sebagai infrastruktur pembelajaran, sumber bahan ajar, alat bantu dan fasilitas pembelajaran, skill dan kompetensi, sumber informasi penelitian, media konsultasi, dan media belajar online. Banyaknya manfaat TIK dalam pendidikan, menjadikannya salah satu indikator kompetensi yang ada pada guru (Sudarmanto, 2009). Oleh karena itu, guru di samping memiliki kemampuan mengajar di kelas juga harus mampu mengintegrasikan pemanfaatan TIK dalam pembelajaran. Kompetensi TIK guru menjadi suatu hal yang menjadi perhatian bagi pemerintah sehingga pemerintah menjalankan berbagai program sarana belajar berbasis TIK. Seperti: membaTIK (membuat bahan ajar berbasis TIK), situs rumah belajar, lomba kihajar dewantara, Mobile Edukasi, TV Edukasi, iPerpusnas, dan lain sebagainya. Berbagai program tersebut merupakan salah satu cara pemerintah memotivasi dan meningkatkan kompetensi TIK guru.

Seiring dengan perkembangan TIK yang semakin pesat, kondisi kompetensi TIK guru di Indonesia masih berada pada kategori cukup atau di bawah kategori baik, dimana masih banyak guru yang tidak mengetahui tentang penguasaan aplikasi dasar, kebijakan pemerintah terkait penggunaan TIK di sekolah, prinsip-prinsip dan desain pengembangan bahan ajar menggunakan TIK, dan aturan penggunaan perangkat keras dan perangkat lunak TIK di dalam kelas/sekolah. Hal ini di perkuat oleh data tentang hasil uji kompetensi guru (UKG) tahun 2019 juga memberikan gambaran tentang rendahnya kompetensi guru di Indonesia. Rata-rata nilai yang diperoleh guru adalah 54,35, sedangkan nilai minimum yang ditetapkan pemerintah adalah 56,69 (Kemendikbud RI, 2019).

Dalam menyelesaikan permasalahan yang muncul mengenai kompetensi TIK guru, tidak hanya pemerintah, kepala sekolah mempunyai 
peran yang sangat besar dalam meningkatkan kompetensi TIK pada guru (Ghofar, 2013). Sebagai pemimpin yang menggerakkan semua guru yang ada disekolah.

Salah satu peran kepala sekolah dalam meningkatkan kompetensi teknologi informasi dan komunikasi adalah peran kepala sekolah sebagai educator (El, 2019; Siregar, 2019). Peran kepala sekolah sebagai edukator (pendidik) yaitu harus memiliki strategi yang tepat untuk meningkatkan profesional tenaga kependidikan di sekolahnya, Menciptakan iklim sekolah yang kondusif, memberikan nasehat kepada warga sekolah, memberikan dorongan atau motivasi kepada seluruh tenaga kependidikan dan mengadakan program bagi guru dan peserta didik (Khoiri, 2020).

Salah satu kepala sekolah yang telah menerapkan pembelajaran dengan memanfaatkan TIK, jauh sebelum pembelajaran jarak jauh di adakan karena adanya wabah virus corona adalah Kepala SMP Negeri 10 Palembang. Pada tahun 2019 Kepala SMP Negeri 10 Palembang membuat suatu pembelajaran kebijakan tentang penggunaan aplikasi qualitiva dalam proses. Qualitiva adalah aplikasi sekolah online yang dapat digunakan setiap hari oleh sekolah, siswa dan orang tua untuk berbagi materi pelajaran, melaksanakan ujian daring, sampai mendapatkan rekapitulasi nilai otomatis, tersedia juga fitur tambahan lainnya mulai dari diskusi online hingga berbagi berita dan pesan dari sekolah untuk siswa dan orang tua (https://www.qualitiva.id/).

Penggunaan aplikasi ini merupakan salah satu strategi dan upaya kepala sekolah dalam meningkatkan kompetensi TIK guru dikarenaka dengan menggunakan aplikasi pada pembelajaran, guru dituntut untuk belajar bagaimana membuat soal melalui qualitiva, pembuatan materi, absen, serta video pembelajaran melalui aplikasi qualitiva. Penggunaan aplikasi qualitiva dimulai sejak semester genap tahun 2019, dimana pada saat saat itu penilaian harian bersama (PHB), penilaian tengah semester (PTS), penilaian akhir semster (PAS) menggunakan aplikasi ini. Aplikasi qualitiva ini tidak hanya berguna bagi guru dan siswa saja, melainkan juga berguna bagi orang tua, yang mana orang tua dapat melihat bagaimana hasil ataupun nilai anak-anaknya.

Dari observasi peneliti, kepala sekolah mempunyai kemauan yang kuat dalam memperbaiki kualitas pembelajaran dengan menggunakan TIK. Hal tersebut dilihat dari kemauanya bekerjasama dengan anak perusahaan dari palcomtec dalam pemakaian aplikasi qualitiva dan juga pelatihan yang diselenggarakan oleh tim qualitiva. Terlebih lagi dengan adanya kebijakan dari pemerintah mengenai penyelenggaraan pembelajaran jarak jauh. Sesuai Surat Edaran No 4 tahun 2020 tentang pelaksanaan kebijakan pendidikan dalam masa darurat Covid-19 Hal tersebutlah yang membuat peneliti tertarik untuk 
mengkaji mengenai peran kepala sebagai educator dalam meningkatkan kompetensi Teknologi Kompetensi dan Informasi guru di SMP Negeri 10 Palembang. Adapun tujuan penelitian ini adalah untuk menganalisis peran kepala sekolah sebagai educator dalam meningkatkan kompetensi, untuk menganalisis kompetensi TIK Guru, dan untuk mengetahui faktor pendukung dan faktor penghambat bagi kepala sekolah dalam meningkatkan kompetensi TIK di Sekolah menengah Pertama Negeri 10 Palembang.

Melihat hasil penelitian-penelitian terdahulu memperlihatkan perbedaan dengan penelitian yang dibahas oleh penulis saat ini. Titik fokus dari penelitian yang akan dibahas dalam tulisan ini adalah bagaimana peran kepala sekolah sebagai educator untuk meningkatkan kemampuan para guru dalam bidang teknologi informasi dan komunikasi. Dalam hal ini penulis lebih dalam akan mengkaji program yang telah dijalankan oleh kepala sekolah untuk meningkatkan kompetensi guru.

\section{METODE PENELITIAN}

Jenis penelitian yang digunakan adalah penelitian deskriptif dan menggunakan pendekatan kualitatif. Menurut Sugiono penelitian kualitatif adalah suatu cara ilmiah (rasional, empiris, dan sistematis) untuk memperoleh data empiris (yang teramat oleh indra manusia, valid, reliabel, dan objektif dengan tujuan dan kegunaan (penemuan, pembuktian, atau pengembangan pengetahuan, tindakan dan produk) tertentu (Sugiyono, 2011:3). Pendekatan yang digunakan dalam penelitia ini adalah pendekatan kualitatif (Sudarmanto, 2009). Data yang diperoleh meliputi transkip interview, catatan lapangan berupa foto, dokumen pribadi dan lan-lain yang menggambarkan bagaimana pelaksanaan tata kelola administrasi pada siswa di Madrasah Tsanawiyah Darul Jannah Muara Burnai II Kabupaten Ogan Komering Ilir dilaksanakan dan apa saja faktor pendukung dan penghambat proses pelaksanaan tata kelola administrasi tersebut. Dalam penelitian ini peneliti menggunakan dua teknik analisis data yaitu analisis data tunggal dan analisis lintas kasus, hal ini dikarenakan objek penelitian lebih dari satu sehingga membutuhkan analisis lintas kasus untuk menarik kesimpulan. Analisis data dilakukan dengan mereduksi data, penyajian data dan penarikan kesimpulan.

\section{HASIL DAN PEMBAHASAN}

Pada hasil penelitian, penulis mendeskripsikan bagaimana hasil penelitian didapatkan berdasarkan metode yang digunakan. Hasil penelitian di rangkum secara singkat padat dan jelas yang menjawab permasalahan dalam artikel ini. 
1. Peran kepala sekolah sebagai educator dalam meningkatkan kompetensi Teknologi Informasi dan Komunikasi Guru di SMP Negeri 10 Palembang

Menurut Mulyasa bahwa peran kepala sekolah sebagai educator (pendidik) meliputi mempunyai strategi yang tepat untuk meningkatkan profesional tenaga kependidikan di sekolahnya, Menciptakan iklim sekolah yang kondusif, memberikan nasehat kepada warga sekolah, memberikan dorongan kepada seluruh tenaga kependidikan (Mulyasa, 2007). Adapun peran yang dilakukan kepala sekolah sebagai educator SMP Negeri 10 Palembang, sebagai berikut:

a. Strategi Kepala Sekolah dalam Meningkatkan Kompetensi Teknologi Informasi dan Komunikasi di SMP Negeri 10 Palembang

Strategi menurut Fatimah dan Ratna Dewi merupakan suatu teknik yang digunakan untuk mencapai suatu tujuan (Fatimah dan Dewi, 2018). Pada penulisan ini yang dimaksud dengan strategi kepala sekolah adalah suatu teknik yang dilakukan kepala sekolah untuk meningkatakan kompetensi Teknologi Informasi dan Komunikasi (TIK) guru di SMP Negeri 10 Palembang. berdasarkan hasil penelitian yang dilakukan peneliti bahwa strategi kepala sekolah yaitu mengadakan pelatihan TIK berupa workshop maupun BIMTEK yang membahas tentang penyusunan perangkat pembelajaran, pembelajaran online dan penyusunan soal asesmen, menerapkan sistem tutor sebaya yaitu belajar melalui teman, menerapkan kebijakan tentang pemakaian aplikasi qualitiva sebagai sarana pembelajaran, dan memberikan pengetahuan tentang TIK melalui link-link teknologi pembelajaran.

b. Menciptakan Iklim yang Kondusif untuk meningkatkan Kompetensi Teknologi Informasi dan Komunikasi di SMP Negeri 10 Palembang

Menciptakan iklim sekolah yang kondusif merupakan salah satu peran kepala sekolah sebagai educator. Dalam pembahasan ini peneliti menemukan kegiatan kepala sekolah di SMP Negeri 10 Palembang dalam meningkatkn kompetensi TIK guru di SMP Negeri 10 Palembang, hal tersebut meliputi pengadaan rapat setiap satu bulan sekali pada masa pandemi ini dengan membahas permasalahan yang ada, menetapkan aplikasi pembelajaran yang mudah dan efisien penggunaanya, menyediakan fasilitas laboratorium komputer, wifi dan buku-buku penunjang.

c. Memberikan Nasehat Kepada Guru untuk Meningkatkan Kompetensi Teknologi Informasi Guru di SMP Negeri 10 Palembang

Berdasarkan penelitian yang sudah dilakukan oleh peneliti, baik secara observasi, wawancara maupun dokumentasi, peneliti 
menemukan beberapa temuan mengenai nasehat yang sering kali disampaikan oleh kepala sekolah kepada guru-guru di SMP Negri 10 Palembang untuk meningkatkan kompetensinya dalam bidang Teknologi Informasi dan Komunikasi (TIK) yaitu mengingatkan agar para guru terus meningkatkan kompetensi pada Teknologi Informasi dan Komunikasi dan mengingatkan terus menerus bahwa saat ini teknologi sangat penting bagi pembelajaran dan untuk terus belajar mengenai penggunaan teknologi.

d. Motivasi Kepala Sekolah dalam Meningkatkan Kompetensi Teknologi informasi dan Komunikasi di SMP Neferi 10 Palembang

Motivasi adalah dorongan atau rangsangan yang diberikan kepada seseorang agar memiliki kemauan untuk bertindak. Dorongan ini dapat berupa dilakukan dengan berbagai cara seperti meningkatkan upah yang kerjanya, reward, dan imbalan yang merupakan bonus tertentu, aturan-aturan dan sanksi-sanksi yang ketat bagi pelanggar aturan dan sebagainya (Hikmat, 2009). Dalam teori Maslow dalam Hikmat ia mengemukakan bahwa "orang adalah makhluk yang berkeinginan, ia selalu ingin dan ingin lebih banyak, proses ini tiada berhenti. Suatu kebutuhan yang telah memuaskan tidak menjadi motivator prilaku, hanya kebutuhan-kebutuhan yang belum terpuaskan menjadi motivator prilaku, kebutuhan manusia tersusun dan berjenjang". Menurutnya bahwa, ada lima macam jenjang kebutuhan yaitu kebutuhan fisik, Kebutuhan keselamatan dan keamanan, kebutuhan berkelompok, kebutuhan penghormatan dan kebutuhan pemuasan diri (Himkat, 2009).

Berdasarkan penelitian yang telah dilakukan oleh peneliti tentang motivasi yang diberikan oleh kepala sekolah terhadap guru untuk meningkatkan kompetensi TIK yaitu memberikan pujian-pujian kepada guru yang telah melaksanakan tugasnya dengan baik, dan juga memberikan teguran kepada guru yang lalai terhadap tugasnya.

2. Kompetensi Teknologi Informasi dan Komunikasi Guru di SMP Negeri 10 Palembang

Kompetensi Teknologi Informasi dan Komunikasi (TIK) guru adalah suatu kemampuan yang dimiliki oleh seorang guru meliputi aspek pengetahuan tentang TIK, dan keterampilan dalam menggunakan dan merekayasa pengetahuan dengan TIK (Sari, 2017).

Menurut Munir dalam buku Kurikulum Berbasis TIK, mengatakan bahwa kehadiran TIK dalam pendidikan bisa dimaknai dalam tiga 
paradigma, yaitu TIK sebagai alat atau berupa produk teknologi yang bisa digunakan dalam pendidikan, TIK sebagai konten atau sebagai bagian dari materi yang bisa dijadikan isi dalam pendidikan, dan TIK sebagai program aplikasi atau alat bantu pembelajaran dan manajemen yang efektif dan efisien (Munir, 2009)

Ketiga paradigma tersebut disinergikan dalam sebuah kompetensi yang harus dimiliki oleh guru TIK diantara kompetensi TIK yang harus dimiliki oleh guru adalah sebagai berikut

a. Mengetahui dan mahir dalam operasi komputer dan perangkat lain Teknologi Informasi dan Komunikasi (TIK) yang menunjang

Berdasarkan penelitian yang telah dilakukan oleh peneliti, kemahiran guru dalam mengoperasikan komputer meliputi menghidupkan dan mematikan computer, membuka dan menutup file, Menyalin (back-up) data, Menghapus file, membuat folder, Memindah atau mengcopy data antar disk penyimpanan. Menghubungkan computer ke internet. Selain mahir dalam mengoperasikan komputer guru juga mahir mengoprasikan perangkat lain diantaranya:

1) Menggunakan software aplikasi meliputi membuat dokumen dengan menggunakan microsoft word seperti RPP dan Silabus, memodifikasi dokumen yang sudah ada di komputer, mencetak dokumen, menempatkan gambar ke dalam dokumen, mengolah kata yang dilengkapi dengan fitur table, dan membuat multimedia presentasi dengan Micsrosoft Power Point.

2) Menggunakan internet meliputi penggunaan website, mengirim pesan melalui email, menggunakan website untuk mendapatkan informasi terkait pembelajaran, menggunakan fasilitas obrolan chat, mendownload file dari internet, menyimpan gambar dari internet

3) Menggunakan laman website meliputi mencari informasi dari google, menggunakan kata kunci/frase untuk mencari informasi, menggunakan teknik pencarian yang cepat melalui kata kunci/ frase, mencari informasi web-web yang berguna, menggunakan informasi dari web dalam proyek atau tugas, copy atau paste informasi dari web ke dalam dokumen pribadi dan menggunakan alamat web yang sudah diketahui untuk mencari informasi yang bermanfaat

Adapun beberapa yang belum bisa dilakukan oleh sebagian guru adalah menginstal software ke komputer, membuat halaman web, membuat grafik menggunakan microsoft excel, dan menggunakan penanda untuk mempermudah mengunjungi alamat web yang pernah dibuka 
b. Memiliki kemampuan dalam pemilihan software pengajaran

Pemilihan software pengajaran yang tepat merupakan langkah strategis guru untuk memaksimalkan proses pembelajaran itu sendiri. software pengajaran memilki manfaat yang luar biasa dalam proses pembelajaran diantaranya adalah meningkatkan efektivitas dari proses belajar mengajar terutama untuk interaksi antara guru dan siswanya. Berdasarkan penelitian yang telah dilakukan bahwa pemilihan software pengajaran yang dilakukakan para guru berdasarkan kondisi anak, kemampuan guru, software yang praktis, simpel dan efisien, software yang multifungsi.

Beberapa software pengajaran yang dipakai dalam pengajaran yaitu,

1) Aplikasi qualitiva, aplikasi qualitiva digunakan saat pembelajaran langsung maupun pembelajaran jarak jauh, penggunaan aplikasi qualitiva ini digunakan ketika penilaian harian bersama (PHB), penilaian tengan semester (PST), penilaian akhir semester (PAS), selain itu juga, aplikasi qualitiva digunakan untuk memberikan materi kepada siswa, sebagai absensi siswa serta dapat di integrasikan dengan video pembelajaran. beberapa kekurangan dalam pemakaian aplikasi ini adalah jaringan internet yang error dari pusat dan juga tidak bisa melihat siswa seperti pembelajaran langsung.

2) Power point, software ini biasa digunakan guru sebagai media pembelajaran yang dibantu dengan proyektor. Powerpoint ini dugunakan untuk mempresentasikan materi pembelajaran yang dibuat seunik mungkin sehingga siswa tertarik untuk melihat dan mendengarkan materi pembelajaranya. Kekurangan yang ada pada software ini adalah beberapa guru kurang kreatif dalam memanfaatkan software ini sehingga pembelajaran menjadi monoton dan membuat siswa mudah merasa bosan.

3) Zoom, software ini hanya digunakan oleh beberapa guru saja, dan digunakan saat pembelajaran jarak jauh. Penggunaan aplikai zoom hampir sama dengan tatap muka langsung dikarenakn guru bisa melihat siswa dan siswa juga bisa melihat gurunya. Software ini dapat diintegrasikan oleh software lainya seperti power point, chat, dan video. Namun beberapa kekurangan yang ada pada software ini adalah membutuhkan jaringan internet yang baik, namun beberapa siswa berada dilingkungan yang tidak baik jaringan internetnya. 
4) Google classroom, aplikasi ini digunakan guru untuk memberikan tugas ataupun kuis yang dilaksanakan saat pembelajaran langsung. Google classroom hanya digunakan beberapa guru dan tidak sering. Kekurangan dari aplikasi ini adalah guru tidak bisa mengontrol siswa secara maksimal saat pembelajaran, hal tersebutla yang menjadikan google classroom sebagai media untuk menjawab kuiskuis harian saja saat pembelajaran.

5) Youtube, youtube digunakan guru sebagai penyampaian materi dan juga memberikan sumber-sumber belajar kepada siswa.

c. Mengetahui teknik-teknik pengajaran menggunakan computer

Teknik pengajaran adalah serangkaian cara, upaya dan siasat yang dilakukan oleh guru untuk melaksanakan proses belajar mengajar secara optimal kepada para siswa (Uno, 2009). Teknik pengajaran dapat dilakukan secara konvensional ataupun menggunakan bantuan dari teknologi. Hal tersebut diharapakan agar tujuan pembelajaran dapat tercapai secara optimal. Berikut ini beberapa temuan tentang teknik pengajaran menggunakan komputer yang dilakukan oleh guru di SMP Negeri 10 Palembang.

Berdasarkan penelitian yang telah dilakukan mengenai teknik pengajaran menggunakan komputer yang dilakukan oleh guru di SMP Negeri 10 Palembang, yaitu:

1) Teknik Pembelajaran dengan sistem online

Pada sistem online guru memanfaatkan aplikasi qualitiva, zoom, google classroom, dan video berisi materi pembelajaran sebagai media dan sumber pembelajaran.

2) Teknik pembelajaran dengan sistem offiline

Pada sistem offline (langsung) juga dilakukan dengan menggunakan presentasi power point, video pembelajaran yang diputar di depan kelas menggunakan proyektor, memberikan link-link pembelajaran sehingga siswa dapat mempelajarinya di rumah.

3. Faktor Pendukung serta Penghambat dalam meningkatkan kompetensi Teknologi Informal dan Komunikasi (TIK) guru di SMP Negeri Palembang

a. Faktor pendukung dalam Meningkatkan Kompetensi Teknologi Informasi dan Komunikasi Guru di SMP Negeri 10 Palembang

Faktor pendukung adalah faktor yang mendukung, mengajak,dan bersifat untuk ikut serta dalam dukungan suatu kegiatan. Berdasarkan penelitian yang telah dilakukan oleh peneliti bahwa faktor pendukung dalam meningkatakan kompetensi Teknologi Informasi 
dan Komunikasi (TIK) guru di SMP Negeri 10 Palembang dikelompokkan menjadi dua bagian yaitu:

1) Secara internal meliputi kemauan dan kesadaran guru-guru untuk belajar mengenai Teknologi Informasi dan Komunikasi, peralatan yang memadai seperti laptop dan ruang laboratorium komputer, wifi, latar belakang pendidikan guru, sudah mempunyai narasumber (pembicara) yang bisa dihadirkan ketika pelatihan dan kebijakan kepala sekolah dalam memanfaatkan TIK dalam pembelajaran.

2) Secara eksternal meliputi peran pemerintah seperti bantuan fasilitas TIK sekolah dan mengadakan workshop mengenai pemanfaatan TIK, dan peran lembaga swasta pada bidang TIK seperti bekerjasama pada TIM aplikasi qualitiva dalam mengadakan pelatihan.

b. Faktor Penghambat dalam Meningkatkan Kompetensi Teknologi Informasi dan Komunikasi Guru di SMP Negeri 10 Palembang

Faktor penghambat adalah faktor yang sifatnya menghambat jalannya suatu kegiatan dan bersifat seperti menggagalkan suatu hal. Berdasarkan penelitian yang telah dilakukan oleh peneliti bahwa faktor penghambat dalam meningkatakan kompetensi TIK guru adalah keterbatasan kemampuan disebabkan kemampuan dan anggaran pelatihan TIK yang belum dimasukkan dalam anggaran sekolah di awal tahun.

\section{KESIMPULAN}

Peran kepala sekolah sebagai educator dalam meningkatkan kompetensi dapat dilakukan dengan mengadakan pelatihan, rapat, mengingatkan agar para guru terus meningkatkan kompetensi dan memberikan pujian-pujian kepada guru yang telah melaksanakan tugasnya dengan baik, dan juga memberikan teguran kepada guru yang lalai terhadap tugasnya. Kompetensi yang dimiliki guru di SMP Negeri Palembang meliputi mampu mengoperasikan komputer, menggunakan software aplikasi, dan menggunakan laman website, pemilihan software pengajaran yang dilakukakan para guru berdasarkan Kondisi anak, kemampuan guru, software yang praktis, simpel dan efisien, dan software yang multifungsi, software yang digunakan dalam pengajaran yaitu Power Point, Aplikasi Qualitiva, Aplikasi Zoom, Video dan Google Class Room. Teknik pengajaran menggunakan komputer yang dilakukan oleh guru di SMP Negeri 10 Palembang, yaituu sistem online yang memanfaatkan aplikasi qualitiva, zoom, google class room, dan video berisi materi pembelajaran. Sedangkan sistem offiline (tatap muka langsung) yang menggunakan presentasi power point, video pembelajaran 
yang diputar di depan kelas menggunakan proyektor, memberikan link-link pembelajaran sehingga siswa dapat mempelajarinya di rumah. Sedangkan untuk faktor Pendukung secara internal meliputi kemauan dan kesadaran guru-guru, peralatan yang memadai, latar belakang pendidikan guru, narasumber (pembicara) yang siap untuk dihadirkan ketika pelatihan dan kebijakan kepala sekolah dalam memanfaatkan TIK dalam pembelajaran. Secara eksternal meliputi peran pemerintah dan peran lembaga swasta pada bidang TIK. Serta faktor penghambat secara internal meliputi usia guru, dan secara eksternal meliputi anggaran yang digunakan dalam pelatihanpelatihan guru pad bidang TIK.

\section{DAFTAR PUSTAKA}

El, A. S. (2019). Buku Ajar Human Relations. Yogyakarta: Deepublish.

Fatimah., \& Dewi, R. (2018).Strategi Belajar \& Pembelajaran Dalam Meningkatkan Keterampilan Bahasa. Jurnal Pendidikan Bahasa dan Sastra Bahasa, 1 (2).

Ghofar, A. (2013). Belajar dari Masalah: Masalah adalah Hadiah Terindah dari Allah. Balikpapan: LPPM STIS Hidayatullah.

Hikmat. (2009). Manajemen Pendidikan. Bandung: CV. Pustaka Setia.

Kemdikbud RI. (2019). Neraca Pendidikan Daerah 2019.. https://npd.kemdikbud.go.id/?appid=ukg.

Khoiri, A. (2020). Nasehat Tuhanku Untuk Hamba. Bogor: Guepedia.

Mulyasa, E. (2007). Menjadi Kepala Sekolah Profesional. Bandung, PT. Remaja Rosdakarya.

Munir. (2009). Kerangka Kompetensi TIK bagi Guru. Bandung: CV. Alfabeta.

Qualitiva. (2021). Sekolah Online. https://www.qualitiva.id/.

Rivalian.R. (2014). Kompetensi Teknologi Informasi dan Komunikasi Guru dalam Peningkatan Kualitas Pembelajaran. Jurnal Teknodik. 18 (2).

Sari, D. (2017). Kompetensi Teknologi Informasi dan Komunikasi Guru SD/MI: Potret, Faktor-Faktor, dan Upaya Meningkatkanya. Muallimuna, 3 (1).

Siregar, N. (2019). Peran Kepala Sekolah sebagai Manajer dalam Meningkatkan Partisipasi Masyarakat di SD Islam Az-Zahrah. Studia Manageria, 1(1), 57-68.

Sudarmanto. (2009). Kinerja dan Pengembangan Kompetensi SDM. Yogyakarta: Pustaka Pelajar.

Sugiyono. (2011). Statistik Untuk Pendidikan. Bandung: Alfabeta

Uno, H. (2009). Model Pembelajaran: Menciptakan Proses Belajar Mengajar yang Kreatif dan Efektif. Jakarta: Bumi Aksara. 
